\title{
New Hungarian \\ Economic Philosophy to Improve Households' Financial Situation
}

\section{Summary}

As a result of the neoliberal economic philosophical doctrines that spread in the 1980s, decreasing attention was paid by researchers and other experts in the European Union to developments in households' financial position and consumption in boosting economic growth. This is despite the fact that the examples set by the increasingly faster growing countries, especially India, China, Brazil, Mexico and South Africa, seem to markedly confirm that developments in incomes and household consumption have an increasing role in the acceleration of economic growth. As globalization and the 2008 economic crisis undermined the financial position of households in the European Union, and thus also in Hungary, and a growing part of the population was thrust into increasingly deeper poverty, so people started to become once again aware of the actual consequences of deterioration in households' financial position on developments in economic growth. Having recognised all this, the Hungarian government fundamentally altered Hungarian economic policy. Tax hikes were replaced by tax cuts, and previous high taxes were replaced by tax credits to facilitate households' position. In contrast to the previous austerity packages, actions were taken with the primary aim to increase the income left with households. This is also the purpose of the utility cost cut procedure. In this framework, long-term changes were performed with the aim to allow the government ensure public services in the field of waste water management, drinking water, natural gas and electricity supply, district heating, waste incineration and mass catering on a non-profit basis, in order to increase the income

Dr Péter Novoszáth, Associate Professor, National Universitity of Public

Service, Public Finance Research Institute (Novoszath.Peter@uni-nke.hu). 
retained by the population rather than the profit made by public service providers. This article presents the theoretical background to this economic philosophy and the most important social effects of the adopted actions.

Journal of Economic Literature (JEL) code: D1, D6, D7, E2, L3

Keywords: electricity prices for household consumers, financial assets and liabilities of households, household expenditure by consumption purpose, household savings, natural gas prices for household consumers

Developments in households' financial position, which have been in the focus of policy and technical debates going on in emerging markets for a long time, are also increasingly attracting considerable attention in developed countries, especially since the 2008 financial crisis (Ampudia and Ehrmann, 2017; IMF, 2013; World Bank, 2008; World Bank, 2014). Households tend to get into a disadvantaged situation, because they do not facilitate consumption and find it difficult to accumulate wealth.

The principal aim of our research at the Public Finance Research Institute of the National University of Public Service is to provide an in-depth study of the macro- and microeconomic structural information representing developments in household assets and liabilities, in order to

(1) understand the interrelationships between the economic behaviour of households and developments in the various macro-economic variables;

(2) evaluate the effects of the various economic shocks, economic policies and institutional changes on household portfolios and their various dimensions;

(3) identify the various aggregated macro-economic variables that have the highest impact on households' financial position, savings, and developments in relations between consumption and investments;

(4) render the decisions on households' various options and reactions to economic shocks predictable;

(5) create and optimise economic models to realistically demonstrate households' economic behaviour;

(6) provide useful insight into correlations between the economic conduct of households, monetary and fiscal policy, financial stability and economic growth.

\section{DEVELOPMENTS IN HOUSEHOLD EXPENDITURES}

The aggregated demand of an economy comprises the amount of money spent by households on commodities (C), the expenditures on investment projects (I), government expenditures $(G)$ and exports $(X)$ less imports from abroad $(M)$. The standard formula is:

$$
\mathrm{AD}=\mathrm{C}+\mathrm{I}+\mathrm{G}+(\mathrm{X}-\mathrm{M})
$$


Household expenditures are the most important part in the aggregate demand (Howarth, 2015). They can be classified into numerous categories, and include household spending related to transport, food, fuel and clothing.

Figure 1: Household spending in EU, 2016 (\%)

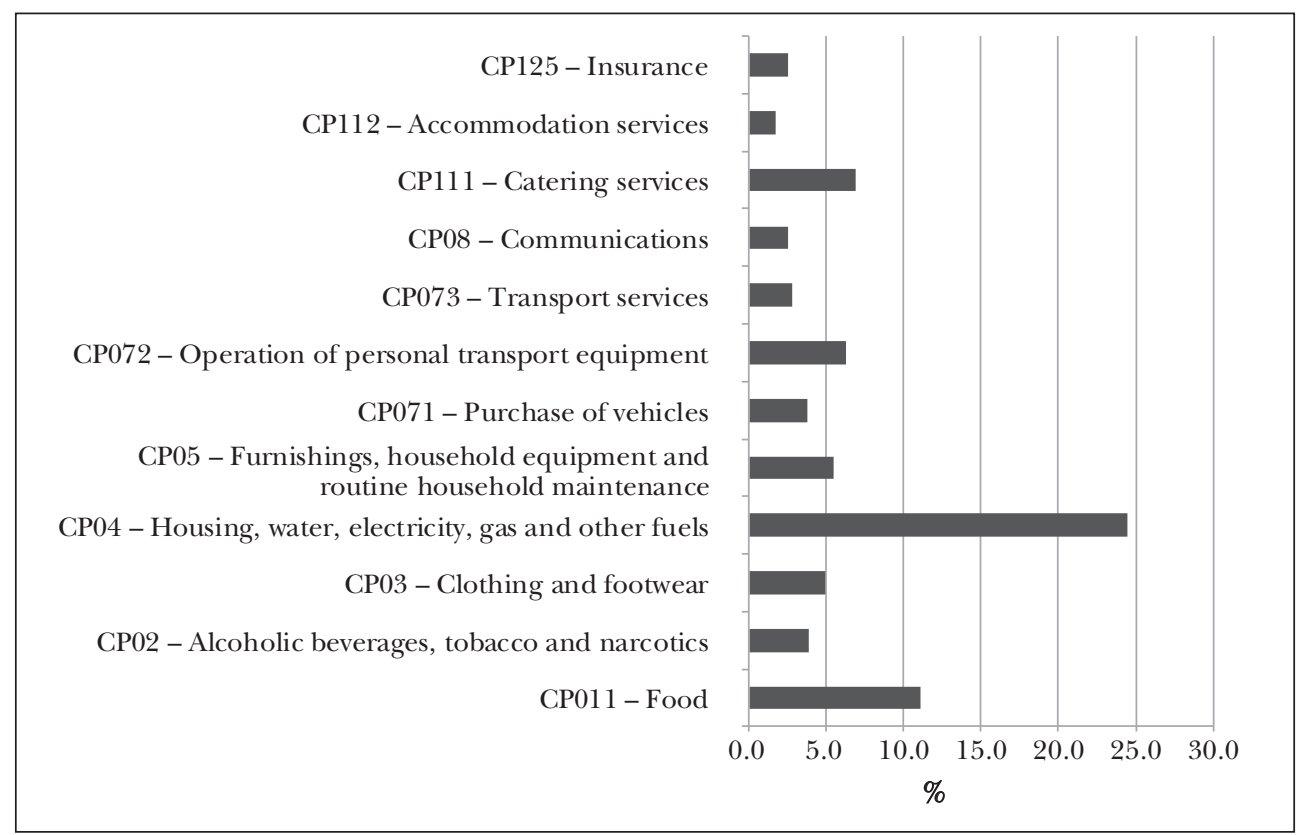

Source: Eurostat, 2016

In the European Union, for example, 76.4 percent of household income was spent on daily expenses in 2016, the highest amount, representing 24.5 percent of all their income spent on overhead costs, while 11.1 percent was spent on food. Figure 1 gives an illuminating presentation of the average amount households spend in a week in the European Union in 2016, in a breakdown of various goods and services.

The composition of household spending changes with their income position and with time. Households spend the overwhelming majority of their income on commodities and services required for their standard everyday life, but certain goods and services are not indispensable and do not closely relate to their daily activities. For this reason, increase in incomes encourages households to spend the increment on products representing highly flexible income in their demand, like summer holidays or recreation, as against low income-flexibility foodstuffs. Over time, spending on certain objects and services that come into fashion increases in comparison to those that go out of style. Changes in taxes and subsidies may encourage households to purchase certain products and services or warn them off from buying them. Relative price changes may cause changes in the composition of household consumption, as the prices of certain goods and services may rise in comparison to others. 
Péter Novoszáth: New Hungarian Economic Philosophy to Improve Households' Financial...

\section{Factors determining household expenditures}

The level of spending is determined by numerous factors. First and foremost, changes in the national income, provided that it has a significant impact on the income available for households.

\section{The current level of national income}

In the event of a rise in income, consumers tend to increase their spending on goods and services with higher income flexibility, like for example, luxury products, summer holidays, wellness and leisure-time products and services. In contrast, when their income falls, households postpone expenditures on the most redundant products and services until their income starts to rise again.

\section{The level of savings}

Expenditures and savings mutually exclude each other, which means that if the income becomes fixed, any change in household savings will inversely affect expenditures. Numerous consumption factors will have an inverse impact on savings. Household saving depends on the ratio of the total available income used for consumption: Total available income - consumption $=$ savings $(\mathrm{MNB}, 2017)$.

Any income not used is accumulated in the form of financial or non-financial assets. The accumulation of non-financial assets is presented in capital investments, while the net accumulation of financial investments are accounted as financial savings. (In gross terms, the accumulation of financial assets is considered as investment, and those of liabilities as financing.) Financial savings, also termed net financing capacity, is thus the difference between savings and investments: Savings - investments = financial savings (net lending, net financing capacity).

The total available income comprises incomes from production (in other words, added value), employee incomes, social allowances and proprietary incomes, less any income taxes and social security contributions paid by the households.

\section{Expectations}

If households are confident and have positive expectations for the future, then current expenditures may also rise. This may result in economic growth and enforce the positive expectations.

\section{Unemployment}

Unemployment has two impacts on household expenditures. On the one hand, the unemployed pay less due to their lower personal incomes, and on the other, unem- 
ployment triggers negative expectations, even among the employees, and this may contribute to fall in spending and the encouragement of savings.

Income tax rates

Change in tax rates may clearly affect the disposable income after taxation and thus influence household expenditures.

\section{Interest rates}

Interest rate changes may either encourage or discourage households to save or borrow. The main forms of saving (rise in the rates of deposit interests, government securities, bonds and investment funds) result in more saving and less consumption. On the other hands, increase in the costs, e.g. rates, of debts owed, like mortgage and bank loans, reduce households' financial assets, distracting expenditures towards higher loan instalments and reduces other expenses by households. Rising loan rates may reduce the number of new loans, and there will be a rise in the number of those who postpone borrowing until interest rates start to fall. Expectations and confidence have a significant impact on household behaviour. For example, rising interest rates may erode confidence and cause households take a kind of "wait and see" attitude and postpone certain expenses until prospects start to improve (Howarth, 2015).

\section{THE ROLE OF HOUSEHOLDS IN ECONOMIC DEVELOPMENT}

Due to their consumption, households make one of the key sectors of the economy. Economists usually classify households' contribution to economic performance into two categories. On the one hand, in the form of various factors, they provide services to the economy, and on the other, they generate demand for finished products and services in the market (Seth, 2015).

a) Households provide businesses with such important production factors as land, labour, capital and so on.

b) In the market, it is households that purchase the finished products and services manufactured by businesses.

Households have an enormous role and significance in economic development:

- Households produce a significant part of the products and provide the major part of services. In Hungary there is a high number of family businesses, owning minor production or service provider units. These households are entrepreneurs making various goods and offering diverse services. These businesses employ a significant part of the labour force, they are key economic stakeholders and at the same time they have a peculiar and high significance within households.

- Households purchase a significant part of the manufactured goods and services provided. Households are among the key end-consumers of the goods manufactured and ser- 
vices provided by companies. In accordance with their tastes and preferences, they generate considerable demand for businesses' products and services. For the most part, businesses manufacture their products and services in the market according to households' requirements and demand. For this reason, it is also households that primarily determine the activities of the production line made by businesses.

- Households pay a significant amount of taxes. Households are the government's principal sources of tax income. They are the key taxpayers. Households pay income taxes, employee contributions, at certain places also property taxes, gift taxes and various other contributions, etc. as direct taxes to the central budget. Similarly, households also pay several indirect taxes to the government, like turnover taxes, customs duties, value added taxes, etc. All these tax revenues are collected and used in order to improve the economy and welfare activities.

- Households contribute a significant part of the most varied professions. Most of the professional services, like those provided by physicians, teachers, lawyers and engineers, etc. come from households. These activities are very important for the given country to be able to boost its economic development. These professional services also have a key role in improving people's living standards.

- Households have significant savings. The incomes remaining after consumptions become savings. After having provided numerous services to the economy, they make considerable incomes. For the most part, after consumption they keep their remaining incomes in banks or at other financial institutions. These savings are among the main sources of debt financing and capital investment projects in Hungary (Seth, 2015).

Impacts of the world economic crisis in Europe, decrease in household consumption and prolonged stagnation

In contrast to Asian countries, in the majority of the Member States of the European Union, domestic consumption and domestic demand was not only unable to offset missing export revenues, but rather the reverse: drop in household consumption significantly contributed to the further deepening of economic recession.

In the past decade, the contribution of household expenditures to GDP at any time fell or at most stagnated in several countries. As GDP also declined in several countries due to the crisis, in these countries this meant a decrease in household expenditures in real terms. The most conspicuous decline in household consumer expenditures to GDP was recorded in Luxembourg (10.5\%), Malta (10.4\%), Estonia (10.1\%), Romania (9.8\%) and Cyprus (8.9\%) (Eurostat, 2012).

This procedure is also confirmed, in another respect, by the fact that the number of households in a difficult financial situation gradually increased month by month, and as a result, already before the outbreak of the crisis the purchasing power of households underwent considerable decline in the European Union. In cooperation with BIPE Consulting and Polling Institute, in November and December 2011, Cetelem made an Internet-based survey of more than 6500 interviewees in Europe with 
Table 1: Developments in household consumer expenditures before and after the outbreak of the financial and economic crisis (as a percentage of GDP)

\begin{tabular}{|c|c|c|c|c|}
\hline & 1999 & 2004 & 2009 & 2011 \\
\hline 1 Cyprus & 81.1 & 75.6 & 77.4 & 72.2 \\
\hline 2 Greece & 75.7 & 73.6 & 76.8 & 67,6 \\
\hline 3 Bulgaria & 72.5 & 70.5 & 70.1 & 61,9 \\
\hline 4 Malta & 80.7 & 76.7 & 69.7 & 70.3 \\
\hline 5 Portugal & 62.2 & 62.8 & 63.9 & 67.3 \\
\hline 6 Lithuania & 66.6 & 65.8 & 63.7 & 65.7 \\
\hline 7 United Kingdom & 62.1 & 61.3 & 62.0 & 61.3 \\
\hline 8 Romania & 71.0 & 68.1 & 61.2 & 61.5 \\
\hline 9 Poland & 63.1 & 64.0 & 61.2 & 60.8 \\
\hline 10 Latvia & 61.0 & 61.2 & 61.1 & 62.3 \\
\hline 11 Italy & 60.8 & 59.4 & 60.4 & 61.0 \\
\hline 12 Spain & 63.0 & 60.4 & 59.2 & 56.8 \\
\hline 13 Slovenia & 59.3 & 56.8 & 58.0 & 55.1 \\
\hline 14 France & 55.0 & 55.9 & 57.3 & 53.8 \\
\hline 15 Slovakia & 56.1 & 56.5 & 55.9 & 56.2 \\
\hline 16 Germany & 55.4 & 55.8 & 55.8 & 53.8 \\
\hline 17 Austria & 55.5 & 55.9 & 53.9 & 51.8 \\
\hline 18 Hungary & 56.4 & 54.3 & 53.8 & 51.0 \\
\hline 19 Estonia & 62.0 & 59.3 & 52.9 & 49.2 \\
\hline 20 Finland & 48.3 & 49.2 & 52.2 & 51.0 \\
\hline 21 Czech Republic & 54.7 & 51.5 & 51.0 & 48.4 \\
\hline 22 Belgium & 51.5 & 50.0 & 50.3 & 50.5 \\
\hline 23 Denmark & 48.6 & 47.5 & 48.4 & 46.3 \\
\hline 24 Sweden & 47.4 & 46.4 & 47.8 & 44.9 \\
\hline 25 Ireland & 47.1 & 43.7 & 47.0 & 44.4 \\
\hline 26 Netherlands & 49.7 & 48.3 & 44.9 & 44.1 \\
\hline 27 Luxembourg & 46.9 & 44.3 & 36.9 & 30.0 \\
\hline
\end{tabular}

Source: Eurostat, 2012

the help of the TNS Sofres, and revealed that in the opinions of the majority of middle-class households, their financial position has deteriorated or at least has not improved in the past ten years (Cetelem, 2012).

In the countries surveyed by Cetelem, 60 percent of middle-class European think that their financial position has not improved in the past ten years. This opinion prevailed primarily in Hungary and Italy.

Most respondents mentioned the considerable increase in the costs of living and fall in incomes as the most significant factors in the deterioration of their financial position. Income reduction is less perceptible in Italy and France, however, rise in the 
Figure 2: Why has the financial position of the middle class deteriorated in the past ten years? (Average of the EU12, as a percentage)

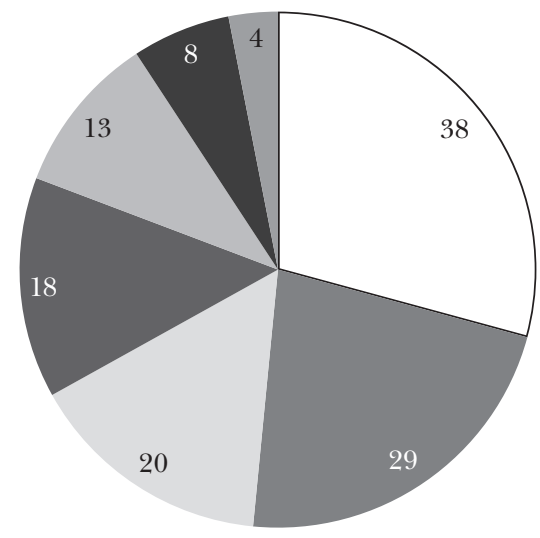

$\square$ Increase in cost of living

Tax increases

- Change of family situation

- Changing consumer habits

Decrease in income

- Increase in health and insurance costs

- Educating children

Source: Cetelem, 2012

costs of living was mentioned in the first place in 11 of the 12 surveyed countries and in the second place in one (it ranked second in the Czech Republic, where it slightly preceded by reduction in incomes). Whether the various daily price hikes (food, fuel, transport, etc.) or rises in the basic costs (rental, overhead, water supply, sewage, electricity, natural gas, telephone, etc.) are taken as a basis, currently they put higher pressure on middle classes as well as wage- and salary-earners because incomes fail to rise as rapidly as costs. In a decade, the ratio of spending on residence, overhead costs, insurance, telecommunication, health and education linked to household budgets rose from 28 to 33 percent (Cetelem, 2012, p. 26).

In the emerging countries of the world, especially in Asia, despite the economic crisis, consumption by the population and the strengthening middle class maintain economic growth and are the number 1 driver of economic development in spite of the missing export revenues. However, as a result of the neoliberal economic philosophical doctrines that spread in the 1980s, decreasing attention was paid by researchers and also practical experts in the European Union to developments in incomes and consumption by the middle class in improving economic growth. Various tightening and cost-efficiency measures are adopted one after the other, and keep curbing the purchasing power of the population and the middle class for more than a decade in most Member States of the European Union. For several years in the Member States of the European Union, and probably for decades in some extremely indebted Member States, household consumption and consumption by the middle class has come to a stagnation, and consequently, market opportunities have shrunk. This is why it was important for the researchers and decision-makers of the 
EU institutions and Member States to re-invent the significance of the financial position of households. The significance of cutting the costs of living, whether overhead or other costs constituting considerable items in the household budget, should not be underestimated on any account in the growth of household purchasing power (Kovács and Novoszáth, 2013).

\section{Developments in Hungarian household incomes}

Household incomes are composed of three major types of incomes: income from work, social allowances and other income. The higher the ratio of income from work, the more favourable the income structure is. Since 2010, the ratio of income from work has increased from 65.3 to 70.1 percent on average (KSH, 2017).

Figure 3: Developments in the per capita income of households (2010-2016)

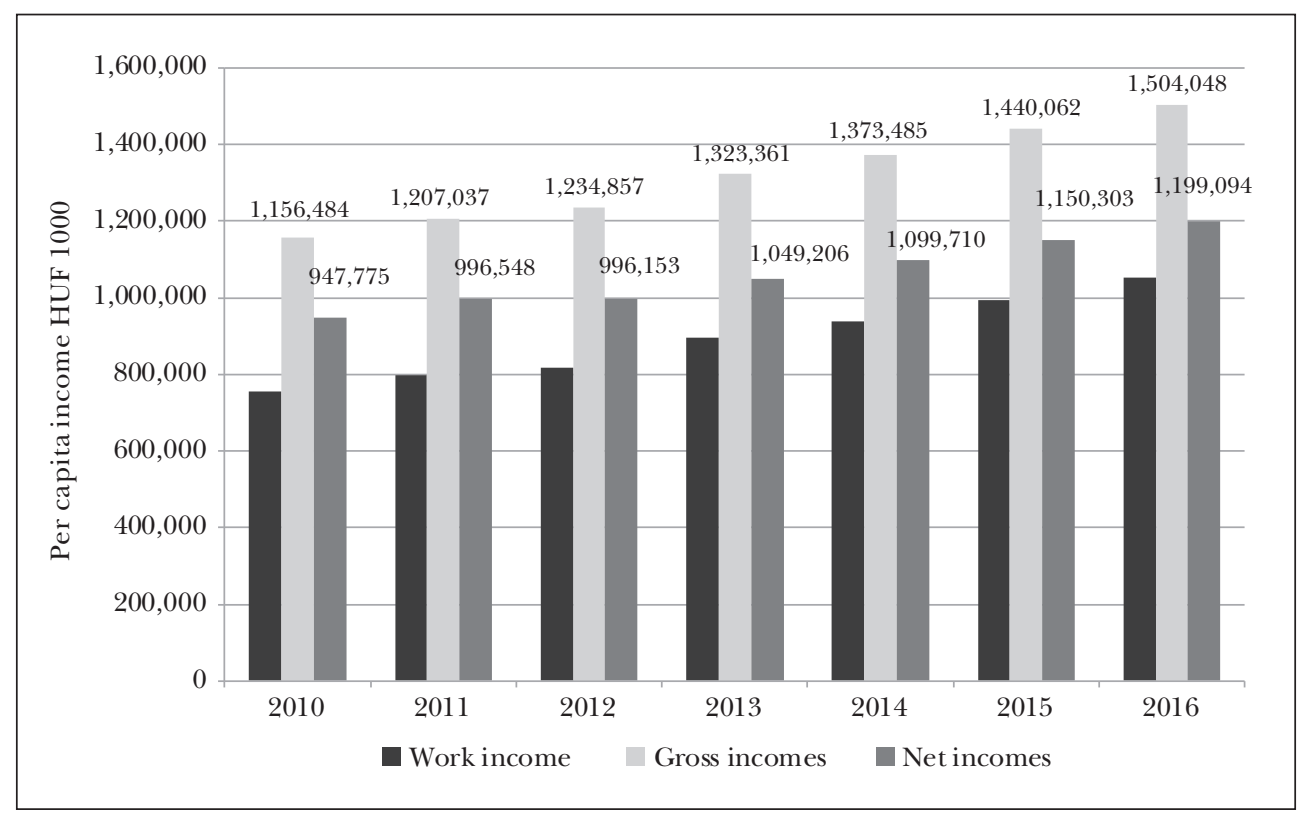

Source: KSH, 2017

The per capita annual average gross income was HUF 1,504,000 in 2016, 4.4 percent higher than in 2015 and 30.05 percent above the corresponding 2010 value. The per capita annual net income was HUF 1,199,000 representing a 4.2 percent rise on 2015 and 26.52 percent on 2010 in nominal terms. Increase in the per capita incomes resulted from the combined effect of two factors: rising wages and allowances, and increase in the number of people employed. As an aggregate outcome of the above, in 2016, the real income was 3.8 percent higher than last year. 


\section{PURPOSE AND AIM OF UTILITY COST GUTS}

Over the past six years, consumption also underwent major changes in terms of structure: the ratio of both power and mainstream gas fell in household energy expenditures (to 33.5 and 35.1 percent, respectively) (KSH, 2017). Hungarian households spend 81 percent of their income on daily expenses, of this, the highest amount, representing 32 percent, is spent on overhead costs, while 31 percent is spent on food. One of the oldest observations in economics, Engel's law states that in the case of households, higher living standards entail a lower ratio of spending on food. For this reason, reducing value added tax on fundamental foodstuffs is important for the population with income below the average. In addition to saving several tens of thousands of forints per year, it also guarantees safe livelihood for the majority of the population.

An analysis of the composition of consumption also reveals that while during the 2005 data recording, the housing costs 25 percent of all expenditures, by 2012 this item had already amounted to 33 percent. In the eight-year period immediately preceding 2012, a drastic rise was seen in housing costs within all household expenses. During the regimes prior to 2010, certain public utility service providers were given the opportunity to increase prices on 15 occasions. As a result, after the year 2000, the prices of all kinds of energy grew faster than the average price. The most rapid increase was recoded in natural gas prices (Századvég, 2014).

For example, in 2007 in Hungary gas prices skyrocketed despite their fall elsewhere in the world. As a result, by 2010 the price charged for natural gas in Hungary had grown to one of the highest in Europe. This is why the government formed in 2010 launched its utility cost cut programme. The main goal of the programme was to set public utility prices families could afford. Hungarian families should have access to the cheapest energy in Europe. Naturally, a minimum profit must be ensured for the public utility service provider to be able to finance improvement in its services and maintain the security of supply, but such profit should not be unlimited, as they wished.

Table 2: Utility cost cutting steps

\begin{tabular}{|c|c|c|c|c|c|c|c|c|}
\hline \multicolumn{9}{|c|}{ Utility Cost Cuts (Phases 1, 2 and 3) } \\
\hline & \multicolumn{4}{|c|}{2013} & \multicolumn{4}{|c|}{2014} \\
\hline & 1 Jan. & 1 July & 1 Nov. & Total & 1 April & 1 Sept. & 1 Oct. & Total \\
\hline Natural gas & $-10 \%$ & & -11.1 & $-20 \%$ & $-6.5 \%$ & & & -25.19 \\
\hline Electricity & $-10 \%$ & & -11.1 & $-20 \%$ & & $-5.7 \%$ & & -24.55 \\
\hline District heating & $-10 \%$ & & -11.1 & $-20 \%$ & & & $-3.3 \%$ & -22.63 \\
\hline Water supply + sewage & & $-10 \%$ & & $-10 \%$ & & & & $-10 \%$ \\
\hline PB gas & & $-10 \%$ & & $-10 \%$ & & & & $-10 \%$ \\
\hline Waste & & $-10 \%$ & & $-10 \%$ & & & & $-10 \%$ \\
\hline \multirow[t]{2}{*}{ Chimney sweeping } & & $-10 \%$ & & $-10 \%$ & & & & $-10 \%$ \\
\hline & \multicolumn{2}{|c|}{ Phase 1} & Phase 2 & & \multicolumn{3}{|c|}{ Phase 3} & \\
\hline
\end{tabular}

Source: Horváth, 2016 
The first phase of utility cost cuts started on 1 January 2013. The price of natural gas, electricity and district heating was reduced by 10 percent, and this action was followed by proposals and actions for similar cuts in household PB gas, waste disposal, water supply, sewerage and chimney sweeping fees. On 29 April, the National Assembly codified utility cost cuts in law (Act LVI of 2013).

As a result of the utility cost cut actions performed in Hungary, the prices of natural gas, electricity and district heating were reduced in three steps by 25.19, 24.55 and 22.63, respectively, in 2013 and 2014. The fees charged for water supply and sewerage, the provision of $\mathrm{PB}$ gas, waste disposal and chimney sweeping decreased by 10 percent.

According to the statements made by Eurostat, in the first part of 2010, Hungary ranked 17th in the list of European countries in terms of natural gas prices, but in the first half of 2017, Hungary had the 3rd lowest natural gas price (Figure 4).

Figure 4: Average gas price for households per $100 \mathrm{kWh}$ in 1st half of 2017 (EUR, all taxes and levies included)

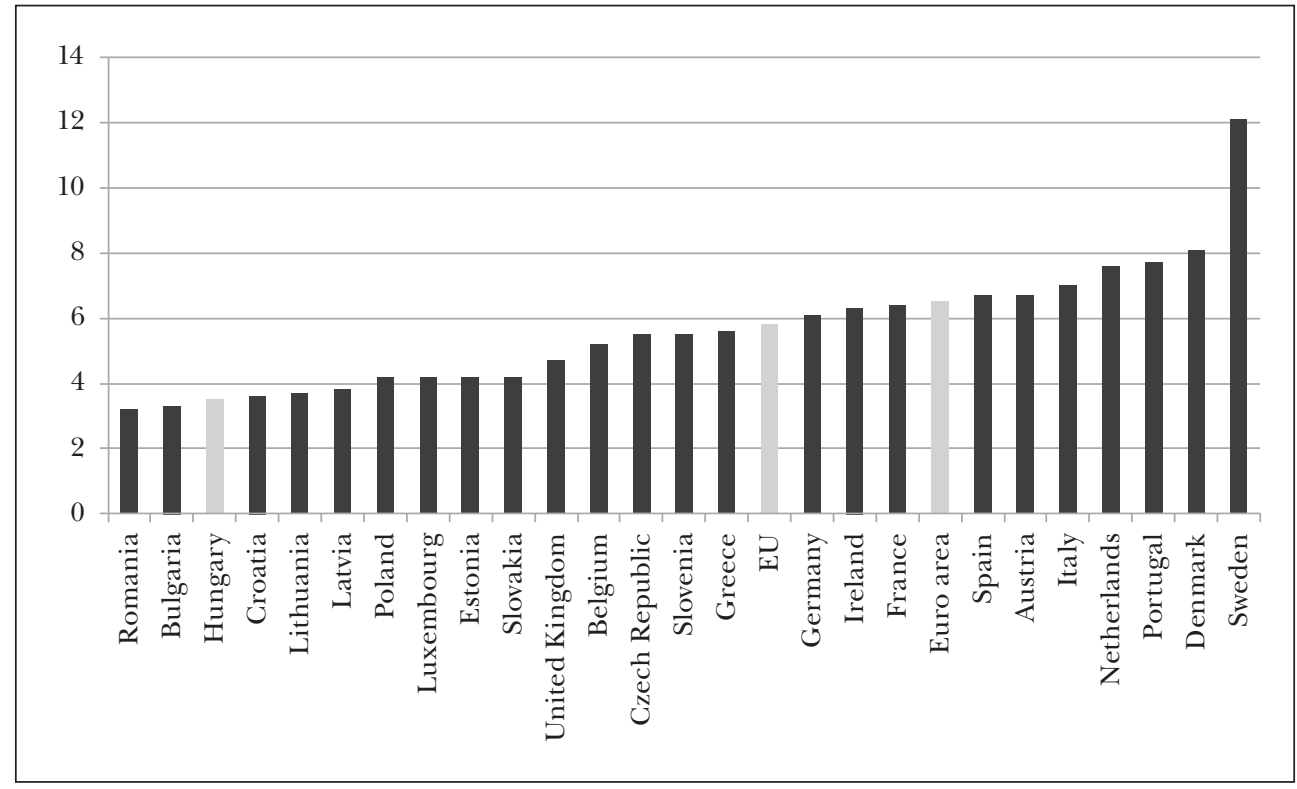

Source: Eurostat, 2017

In respect of electricity prices, in the first part of 2010, Hungary ranked 16th in the list of European countries, but in the first half of 2017, Hungary was already the 3rd cheapest country. In the period between 1 January and 31 December 2013, the Hungarian population could save HUF 642 billion as a result of utility cost cuts. Consumers saved most on electricity: HUF 278 billion, while in the case of natural gas, the total amount saved by the population amounted to HUF 240 billion. Currently, households save HUF 268 billion annually. 
Based on the data provided by the Hungarian Energy and Public Utility Regulatory Authority, a retired couple can save about HUF 83-116 thousand a year, while a family with two children pay HUF 109-112 thousand less.

The housing problems affecting the highest number of people are overhead costs, rent and overdue home loans. According to a European survey, 26 percent of the population, i.e. 2.6 million people are in arrears with due household payments. This includes overdue public utility fees in a considerably higher number of cases (2.3 million people) than arrears with rent or home loan repayment $(680,000$ people), and 63 percent of those who live on incomes below the poverty threshold, placing Hungary last in the list in 2013 (Koltai, 2014).

Utility cost cuts also had a beneficial impact on the fate of previously accumulated arrears. Between 2012 and 2016, overdue accounts payable in natural gas, electricity and district heating fell by 48 percent (Figure 5).

Figure 5: Amounts outstanding between 2012 and 2016

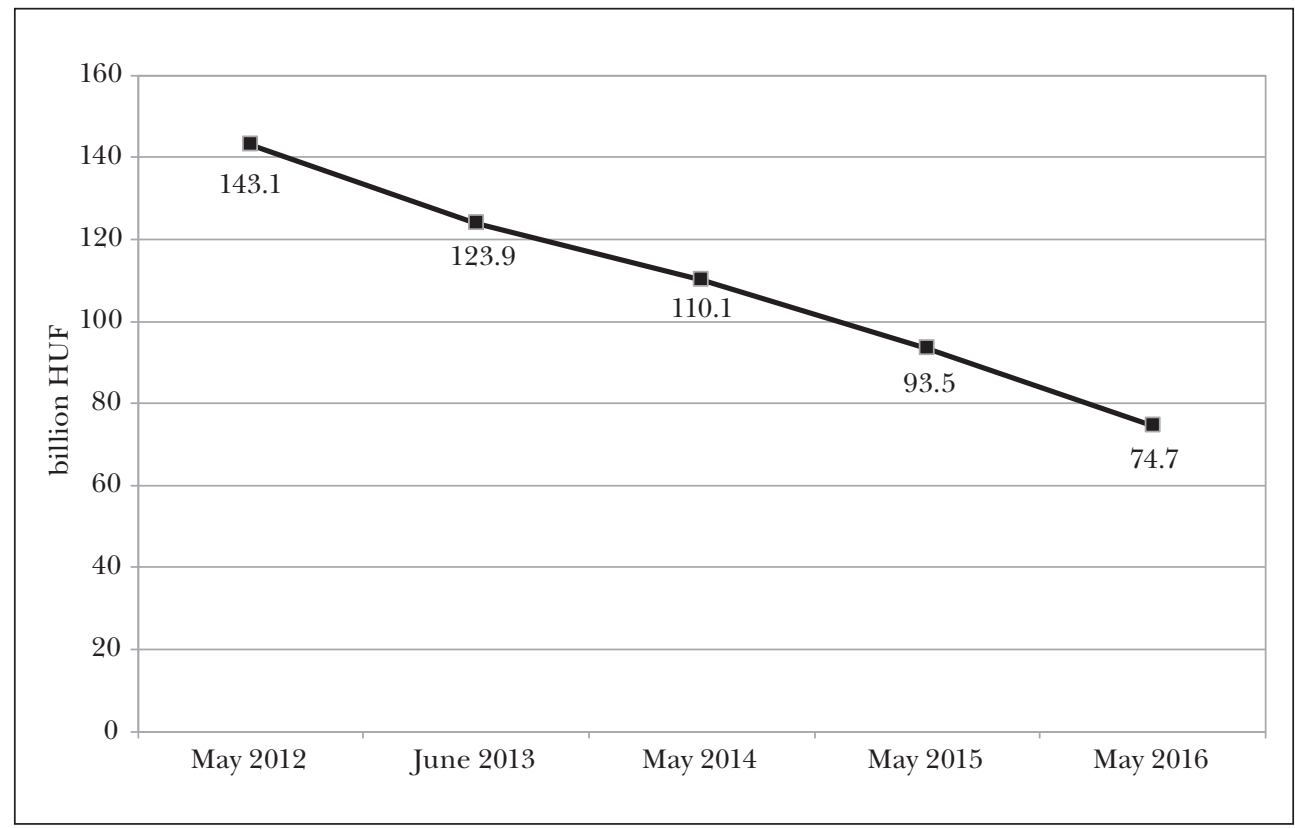

Source: Edited by the author based on Horváth, 2016

Simultaneously, the number of both late paying households and disconnected users have fell considerably in the past few years. The number of defaulting households dropped by 45 percent and disconnected users by 31 percent between 2012 and 2016.

This is not the first case that other European countries follow in the footsteps of the government led by Viktor Orbán. The complete privatisation of the energy and utility service provider sector, and the subsequent rapid rise in the energy prices are 
not isolated phenomena in Europe, however, the powerful countries of the continent have managed to hold the service providers in check. Nevertheless, accompanied by the sympathy of the majority of the population, the British Labour Party campaigned promising to chop energy prices, in accordance with the Hungarian example, during the 2014 general elections in the United Kingdom. During the 2014 general elections, the leader of the British Labour Party promised his electorate to freeze the overhead costs of households and family businesses for 20 months if his party is elected to govern. Ed Miliband thought that the various energy supplier companies have been billing more than justified for too long a time, and they could do it because market competition was insufficient. The politician urged energy suppliers in a letter to help him make his plans work (Baker, 2015). However, the energy service companies responded indignantly to his concepts: they thought that such a decision might even cause power failures.

The British consumer protection organisations, however, pointed out that an increasing number of minimum pensioners and low-income families were incapable of paying their public utility bills. In its 2016 report, CMA established that 90 percent of the domestic energy consumers disconnected from supply in the United Kingdom are simply unable or unwilling to change their energy suppliers (CMA, 2016). According to these, market mechanisms are far from working appropriately and fail to ensure adequate control of the service providers that misuse their market positions and the high-level enforcement of the population's interests. Therefore, it was no accident that during the 2017 general elections, the Labour Party was not the only one to promise the British electorate to prevent increase in the energy-related expenses of households if they are elected, the conservatives did the same. Nevertheless, the policy adopted by rightist conservatives slightly differs from that of the Labour Party, as instead of freezing prices, they promised their constituents the adoption of a new price cap regulation. In their opinion the solution they offered is able to respond to changes in the market conditions considerably more flexibly.

In relation to the debate sparkled around Scottish and Southern Energy (SSE), in November 2016, the six large British energy supplier companies undertook to freeze natural gas and electricity prices for at least six months, up to April 2017. This enabled saving at least some GBP 100 and offering consumers one of the lowest prices in the market. The announcement made by SSE, a company with 8 million consumers, took the other energy suppliers by surprise, as with the winter coming, they rather expected price rises. Simultaneously, SSE's initiative has not made followers up to this very day. Most of them did not even respond to the news, including the British Gas and Npower, while the French EDF only commented, through their spokesperson, that they were continuously monitoring their prices. Journalists cleverly concluded their reports saying that they would inform the public if news of any development whatsoever came in this topic, but since November 2016, not a single statement has been made by any other energy supplier (Borell, 2016).

A 10-percent cut was also made in the Czech Republic, and minor price reductions were performed in Bulgaria and Germany (Magyar Nemzet, 2013). 
In addition to energy price cuts, however, numerous actions have been taken all over the world to mitigate some or another significant household expense. The bestknown examples include various personal income tax reductions and tax credits for families with children or single parents. They also include regulations endeavouring to moderate the prices of banking services and loans. In December 2015, for example, in the United States the Obama administration adopted actions that facilitated access to banking services for millions who did not have a deposit or current account of their own (Timiraos, 2015).

\section{Previously, THE European Commission ONLY BELIEVED IN MARKET OMNIPOTENGE}

Századvég research institute canvassed a representative sample of people by telephone and with the help of questionnaires between 26 and 30 April 2013, interviewing 1000 persons selected at random (Századvég, 2013). According to this survey, a significant majority of the Hungarian population was aware of the criticism of the government's utility cost cut actions. The overwhelming majority (59\%) of those who had heard the opposition parties' criticisms evaluated them as unreasonable. Based on this survey it can also be concluded that the overwhelming majority of the population (82\%) supports utility cost cuts at the same or more than before. Hardly more than one-tenth (11\%) supported these actions less as a result of the criticisms. Thus, overall the April 2013 public opinion polling performed by Századvég confirmed that the majority of the population did not consider the criticism of utility cost cuts justified. Support to these actions by the population remains high.

Contrary to the spirit of the founders of the European Union, the European Commission wants to decide on an increasing number of questions over the heads of nation states. The Brussels bureaucrats want to deny nation states the opportunity to adopt sovereign decisions on controlling public utility service providers.

These issues were touched during the consultation because under the title Energy Union, the European Commission came forward with a proposal to remove the competence to set electricity prices from Member States (Government of Hungary, 2017). Pursuant to the proposal may in Brussels, the Member States would be required to prepare a time-schedule to "release all the regulated prices". Practically, this would put an end to utility cost cuts, and give a carte blanche to large companies once again to freely set utility prices. As this would again be in the interests of transnational companies rather than Hungarian families, the government firmly opposes it.

Despite the facts, the European Commission seems to only believe in the omnipotence of the market and refuses to even consider any alternative solution. With support from the private companies interested in this industry line, in December 2015 the European Union launched an attack against the Hungarian utility cost cut procedure. To prepare for the attack, several Member States were subjected to similar investigations (Somogyi, 2015). The verdict had practically been made: when the investigation was launched, the investigated states had abused their dominant position 
to jeopardise the existence of the privately owned public service provider companies. To date the EU has never started an infringement proceeding against a private energy supplier or public utility provider abusing its dominant position, or even caused damages to consumers by overbilling or shifting its unnecessarily incurred or prodigal costs to consumers.

In its written position the European Commission claims that market liberalisation entails lower costs. In contrast to this, the previous reports of the European Commission clearly reveal that between 2010 and 2015 the consumer price of electricity increased by 20 percent in the Member States (by 50 percent in the United Kingdom and 37 percent in Portugal). Household natural gas prices makes things look even worse: In five years, consumer prices grew by 25 percent on average in the European Union (in Spain, for example, by 72 percent). Meanwhile, utility costs fell in the largest extent in Hungary within the European Union (EC, 2014).

The Hungarian experts representing the European Union's position think that the centrally managed utility cost cuts are less successful than the market coordination pressed by the European Union. In their opinion, in the Czech Republic and in Slovenia, where the household markets have been completely privatised, prices actually dropped far less than in Hungary, but in nominal terms, they are barely less than in the countries where prices have completely been liberalised (Felsmann, 2016).

In contrast to this, the truth is that currently the world's highest energy prices are charged in the European Union, and especially in countries with a fully liberalised market. In recent years the most rapid price hike have been recorded exactly in these countries: in the United Kingdom, for example, prices have risen by more than 50 percent.

In 2010 Slovenia charged the 13th lowest prices, while in 2016 it slipped back to the 17th place. The electricity prices applied in the Czech Republic in 2016 exceeded those in 16 countries (Figure 6). All these clearly confirm that market liberalisation is no solution to price reductions at all, and moreover, they are not efficient enough for an appropriate control.

According to Estonian representative Kaja Kallas, they already have experience in the system recommended by the European Union, which she thinks resulted in utility cost cuts in their country (SZA, 2017). The Estonian electricity price was undoubtedly the 3rd lowest in 2016. However, it was even lower in 2010. Thus, in a comparison, their positon has actually deteriorated rather than improved, while Hungary's position has considerably improved. Figure 6 clearly shows the countries where prices fell and the extent of decrease. Relative to 2010, by 2016 prices have decreased most in Cyprus, Hungary and Malta (Fig. 6).

Utility cost cuts are made in most cases at the expense of the extra profit made by service providers, this is why service providers fight against it using every means and involving the top politicians of the European Union, heads of the individual institutions and professionals and journalists ready to enforce their in a country and across the borders. Under the pressure of the lobbyists of public utility service providers, the bureaucrats of the European Union prepared a complete attack. They intend to 
Figure 6: Average electricity price for households per $100 \mathrm{kWh}$ in 1st half of 2017 (EUR, all taxes and levies included)

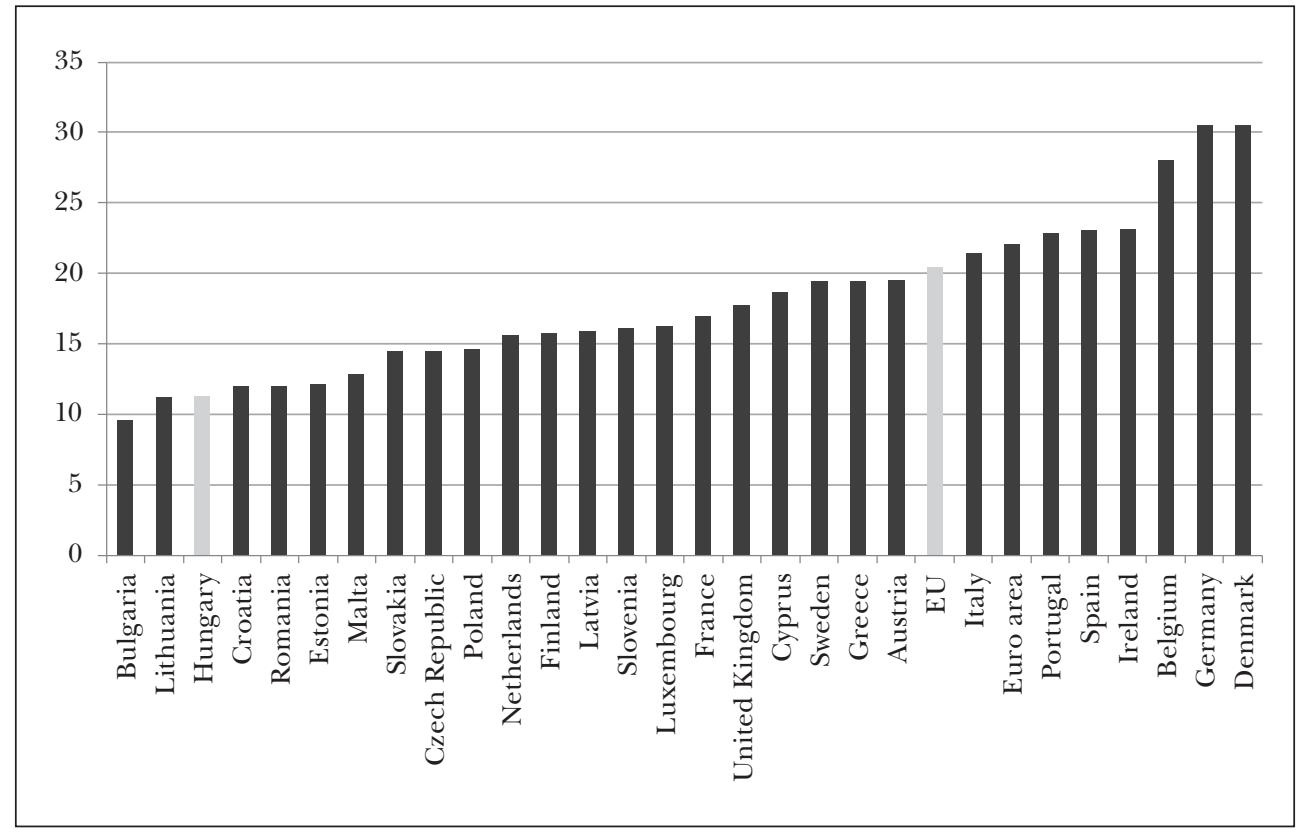

Source: Eurostat, 2017

introduce a uniform regulation all over the European Union that would terminate the opportunity of any kind of price regulation and price control by the Member States. Thus, in the interest of - perhaps unlimited - increase in their profits, public utility service providers could raise the prices of natural gas, electricity and other public utilities several times a year. We would get back to the point where were during the Hungarian governments before 2010: overhead costs would rise drastically, and we could save even less for improving the standard of living, for learning and for healthier life styles, for recreation and having a rest, and for a more meaningful leisure time.

Probably every Member State of the European Union would be capable of what Hungary is doing now: to reduce the prices of energy for households, and subsequently for the entire economy. But we obviously do not want to be deprived of the assets that enable us to make significant achievements. For this reason, Hungary is compelled to defend, in the strongest possible terms, the position it has taken and followed and should not give up the various means of price regulation by the government or the utility cost cut proceedings. If a single energy market that results in the reduction of consumer prices is ever established in Europe, Hungary may also find it attractive to establish such a business environment. However, for the time being, the European Commission should at last prove for its citizens that it is capable of defending citizen interests against the profit interests of a small lobby. In the future it should 
take a stand against private energy or public utility service providers that misuse their dominant positions and cause damages to consumers by overbilling or by shifting their superfluous or prodigal costs to consumers. In order to realise extra profits, they exploit consumers with the European Union's support.

In December 2017 the Energy Council approved the position represented by Hungary about the maintenance of regulated energy prices. Based on the draft directive approved at the council meeting, the Member States may depart from the mandatory phasing off of regulated energy prices, considered as a rule of thumb. Regarding the scope of price regulation and the time period until it needs to be maintained, the practice of European courts should prevail, thus price regulation could be maintained in Hungary for small and medium-size enterprises, households and protected consumers. The adopted general approach ensures a considerably wider elbowroom and powers for Member States to guarantee safe, sustainable and affordable energy supply for consumers, using methods that are the most appropriate for the given country's economic and social conditions (Magyar Idók, 2017).

\section{SUMMARY}

In Hungary, increase in the income and decrease in the burdens of households came into the focus of economy policy decisions after 2010. In this respect, the most important change included personal tax cut. This procedure is still in progress. On the first day of 2016, this tax was cut from 16 to 15 percent, and calculations show that as a result, 4.5 million employees could retain HUF 120 billion. In addition, the situation of approximately 380,000 parents raising two children is also facilitated by the four-year family allowance rising scheme started in 2016. In this scheme, the amount of the monthly allowance due to employees with two children rose from HUF 20,000 to double, in four equal steps of HUF 5000 each, thus in 2019, every beneficiary will be entitled to HUF 40,000 per months as a credit from taxes. Added up, each HUF 5000 allowance enables the affected people to retain HUF 15 billion annually. In the government's concept, the purpose of this credit is to allow parents give their children appropriate education and care. Ultimately, parenthood and parenting should not be tantamount to the assumption of financial difficulties.

In the case of tax cuts, in addition to employers and larger companies, private persons, families with small children and customers at shops could all find their accounts in an amended statutory regulation. The largest change was achieved by the participants of the Hungarian business sector with the multi-annual wage agreement concluded by the government in late 2016 with the interest representation bodies of employees and employers. Pursuant to this agreement, the state undertook to substantially reduce the taxes levied on businesses if employers significantly increase the remuneration paid to their employees. Clause 1 of the agreement entered into force at the beginning of 2017: in January the minimum wage and the lowest wage payable for skilled workers increased by 15 percent and 25 percent, respectively, while in exchange, the government lowered the social contribution levied on companies 
by 5 percentage points. This action relieved the affected parties of taxes and dues in the amount of HUF 400 billion. Pursuant to the agreement, this procedure will continue in 2018: the minimum wage and the guaranteed minimum wage for people with secondary-school qualifications will increase by 8 percent and 12 percent, respectively, and businesses will be able to account another 2.5 percentage point tax credit, representing about HUF 200 billion. This means that in the form of direct tax credits, the government spends significant amounts on enabling businesses to close the gap to the remuneration paid in the western part of the European Union. Citizens' tax position has also been modified.

It is also worth mentioning changes in the rules of paying value added taxes. The government has decided to curb the value added taxes on certain fundamental food products and services. Value added tax was reduced to 5 percent first on pork in 2016, then one year later, on fresh milk, eggs and chicken, and in 2018, also on fish and offal. Value added tax on Internet use, food served and non-alcoholic drinks made in restaurants were also modified: VAT has fallen to 5 percent on both services. In the aggregate it may be established that the most important changes in the period between 2016 and 2018 have brought a drastic reduction in taxes.

As a result of the actions taken, retail trade turnover has been continuously increasing for 52 months. According to the forecast of the National Bank of Hungary (MNB), this rapid growth in incomes and consumption will prevail up to 2020. However, in addition to consumption, household savings also increased significantly after 2010, and in 2015 the level of savings exceeded the level characteristic of 2010 by more than HUF 1200 billion. The following table shows the time series of the transactions performed by Hungarian households, using key economic categories.

Table 3: Developments in household transactions (2006-2015) (HUF billion)

\begin{tabular}{l|r|r|r|r|r|r|r|r|r|r|c}
\hline Item & $\mathbf{2 0 0 6}$ & $\mathbf{2 0 0 7}$ & $\mathbf{2 0 0 8}$ & $\mathbf{2 0 0 9}$ & $\mathbf{2 0 1 0}$ & $\mathbf{2 0 1 1}$ & $\mathbf{2 0 1 2}$ & $\mathbf{2 0 1 3}$ & $\mathbf{2 0 1 4}$ & $\mathbf{2 0 1 5}$ \\
\hline $\begin{array}{l}\text { Total avail- } \\
\text { able income }\end{array}$ & 17,641 & 18,329 & 19,147 & 19,281 & 19,416 & 20,113 & 20,567 & 20,950 & 22,069 & 23,687 \\
\hline $\begin{array}{l}\text { Consump- } \\
\text { tion }\end{array}$ & - & 15,750 & 16,673 & 17,505 & 17,077 & 17,172 & 17,808 & 18,337 & 18,676 & 19,458 & 20,217 \\
\hline Savings & 1891 & 1656 & 1642 & 2203 & 2244 & 2304 & 2230 & 2274 & 2611 & 3470 \\
\hline $\begin{array}{l}\text { Capital in- } \\
\text { vestments }\end{array}$ & - & 1123 & 1249 & 1361 & 1297 & 1060 & 832 & 782 & 817 & 847 & 848 \\
\hline $\begin{array}{l}\text { Financial } \\
\text { savings }\end{array}$ & 768 & 407 & 281 & 906 & 1183 & 1472 & 1448 & 1457 & 1764 & 2623 \\
\hline $\begin{array}{l}\text { Financial } \\
\text { transactions }\end{array}$ & + & 2078 & 1915 & 1678 & 881 & 861 & 525 & 566 & 1027 & 1489 & 1495 \\
\hline $\begin{array}{l}\text { Transac- } \\
\text { tions with } \\
\text { liabilities }\end{array}$ & - & 1310 & 1508 & 1397 & -25 & -322 & -947 & -882 & -430 & -275 & -1128 \\
\hline
\end{tabular}

Source: Edited by the author based on data from the MNB, 2017 


\section{Civic Review · Vol. 14, Special Issue, 2018}

\section{REFERENCES}

Act LVI of 2013 on the Implementation of Utility Cost Cut.

Ampudia, Miguel and Ehrmann, Michael (2017): Financial Inclusion: What's It Worth? ECB Working Paper, No. 1990, January.

Baker, Keith (2015): Metagovernance, Risk and Nuclear Power in Britain. In: Ongaro, Edoardo (ed.): MultiLevel Governance: The Missing Linkages. Emerald Group Publishing, Bingley, pp. 247-271.

Borrell, Lucinda (2016): SEE Freezes Energy Prices Until April 2017 - But You Can Slash Bills By Switching. MSE News, 18 November, www.moneysavingexpert.com/news/energy/2016/11/sse-freezes-pricesuntil-april-2017 (accessed 12 June 2017).

Cetelem (2012): Cetelem Körkép. A középosztály helyzete Európában [Cetelem panorama: The current status of the middle class in Europe]. www.cetelem.hu/files/korkep/korkep_2012_kozeposztaly_helyzete.pdf (accessed 7 May, 2013).

CMA (2016): Energy market investigation. Competition and Markets Authority, 24 June.

EC (2014): Trends and Developments in European Energy Markets 2014. SWD(2014) 310 final, European Commission, 13 October.

Eurostat (2012): Europe in Figures: Eurostat Yearbook 2011. European Commission, www.slideshare.net/ miquimel/eurostat-yearbook-2011 (accessed 6 May 2013).

Eurostat (2016): Final Consumption Expenditure of Households by Consumption Purpose (COICOP 3 digit). http://ec.europa.eu/eurostat/web/products-datasets/product?code=nama_10_co3_p3 (accessed 27 December 2017).

Eurostat (2017): Energy prices 2017. Household energy prices in the EU down compared with 2016. Eurostat Newsrelease, 180/2017, 29 November.

Felsmann, Balázs (2016): Az európai energiaunió és hatásai Magyarországra [The European Energy Union and its impacts on Hungary]. REKK Regional Centre for Energy Policy Research, "Energy Union the Future" conference, Zalaegerszeg, 21 October 2016, http://docplayer.hu/41682319-Az-europaienergiaunio-es-hatasai-magyarorszagra.html (accessed 14 June 2017).

Horváth, Zoltán (2016): A rezsicsökkentés eredményei [Achievements in utility cost cut]. Nemzeti Fejlesztési Minisztérium [Ministry of National Development], VDSZ conference, Budapest, 1 December, 2016.

Howarth, Richard (2015): Macroeconomics for a Level: New Specification. Primedia E-launch LLC.

IMF (2013): World Economic Outlook. Hopes, Realities, Risks. International Monetary Fund, April, Washington DC.

Koltai, Luca (ed.) (2014): Éves jelentés a lakhatási szegénységrôl 2013 [Annual report about housing poverty, 2013]. Habitat for Humanity Magyarország, Budapest.

Kovács, Tamás and Novoszáth, Péter (2013): A jövedelmek, a középosztály fogyasztása, valamint a gazdasági növekedés alakulása közötti összefüggések vizsgálata [Analysis of interrelationships between incomes, consumption by the middle class, and developments in economic growth]. In: Beszteri, Béla (ed.): A felfedezố tudomány [The exploring science]. Conference lectures, Széchenyi István University, Gyôr.

KSH (2017): A háztartások életszínvonala, 2016 [Living standards of households, 2016]. KSH [Central Statistical Office], Budapest, www.ksh.hu/docs/hun/xftp/idoszaki/hazteletszinv/hazteletszinv16. pdf (accessed 9 December, 2017).

Magyar Idôk (2017): Nem követeli Brüsszel a piaci energiaárakat [Brussels does not demand market energy prices]. Magyar Idôk, 20 December, http://magyaridok.hu/gazdasag/nem-koveteli-brusszel-piaci-energiaarakat-2599285/ (accessed 20 December 2017).

Government of Hungary (2017): Összefoglaló a Nemzeti Konzultáció kérdéseivel kapcsolatban [Summary in relation to the questions of the National Consultation]. www.kormany.hu/download/d/1d/01000/ Nemzeti\%20Konzult\%C3\%A1ci\%C3\%B3.pdf (accessed 14 June, 2017).

Magyar Nemzet (2013): Rezsicsökkentés: magyar mintára segítenek a briteken [Utility cost cut: The Hungarian example is followed to help the British]. Magyar Nemzet, 26 September, https://mno.hu/belfold/rezsicsokkentes-magyar-mintara-segitenek-a-briteken-1186533 (accessed 9 June 2017). 
MNB (2017): A háztartási szektor pénzügyi megtakaritásai mikro-és makrostatisztikai adatok alapján [Financial savings in the household sector, based on micro- and macroeconomic statistical data]. MNB, Budapest.

Pickard, Jim and Thomas, Nathalie (2017): Conservatives Promise to Cap Prices in UK Energy Market. Financial Times, April 23, www.ft.com/content/d6f949e2-280b-11e7-bc4b-5528796fe35c (accessed 9 June 2017).

Seth, Tushar (2015): Roles of Households for Building an Economy. www.economicsdiscussion.net/articles/ roles-of-households-for-building-an-economy/2028 (accessed 23 December 2017).

Somogyi, Orsolya (2015): Megvédi a kormány a rezsicsökkentést [The government defends utility cost cut].) Magyar Idók, 3 December.

SZA (2017): „A rezsicsökkentés blöff”, az uniós rendszer múködik [The "utility cost cut bluff”, the system of the European Union works]. HirTV, 6 March, http:/ / hirtv.hu/hirtvkulfold/a-rezsicsokkentes-bloffaz-unios-rendszer-mukodik-1388965 (accessed 14 June 2014).

Századvég (2013): A többség a bírálatok ellenére is támogatja a rezsicsökkentést [The majority supports utility cost cuts despite criticism]. Századvég, www.szazadveg.hu/hu/kutatasok/az-alapitvany-kutatasai/elemzesek-publikaciok/a-tobbseg-a-biralatok-ellenere-is-tamogatja-a-rezsicsokkentest (accessed 9 June 2017).

Századvég (2014): A háztartási energiahordozó árváltozások társadalmi hatásvizsgálata [Impact analysis of changes in the price of household energy carriers]. Századvég Alapítvány, Budapest, 26 August.

Timiraos, Nick (2015): Obama Administration Targets 'Unbanked' Households in New Initiative. The Wall Street Journal, 2 December, www.marketwatch.com/story/obama-administration-targets-unbankedhouseholds-in-new-initiative-2015-12-02-14103286 (accessed 27 December 2017).

The World Bank (2008): Finance for All? Policies and Pitfalls in Expanding Access. Policy Research Report, The World Bank, Washington D.C.

The World Bank (2014): Financial Inclusion. Global Financial Development Report 2014, The World Bank, Washington D.C. 